Summer 2005

\title{
Back to Government? Reregulating British Railways
}

Peter Leyland

London Metropolitan University

Follow this and additional works at: https://www.repository.law.indiana.edu/ijgls

Part of the European Law Commons, International Law Commons, and the Legislation Commons

\section{Recommended Citation}

Leyland, Peter (2005) "Back to Government? Reregulating British Railways," Indiana Journal of Global Legal Studies: Vol. 12 : Iss. 2 , Article 5.

Available at: https://www.repository.law.indiana.edu/ijgls/vol12/iss2/5

This Symposium is brought to you for free and open access by the Law School Journals at Digital Repository @ Maurer Law. It has been accepted for inclusion in Indiana Journal of Global Legal Studies by an authorized editor of Digital Repository @ Maurer Law. For more information, please contact rvaughan@indiana.edu.

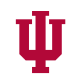

JEROME HALL LAW LIBRARY

INDIANA UNIVERSITY

Maurer School of Law
Bloomington 


\title{
Back to Government? Reregulating British Railways
}

\author{
Peter Leyland*
}

INTRODUCTION

This article examines questions of constitutional accountability arising from the privatization of British Rail in the mid-1990s, but I would like to declare a personal interest in this issue at the outset since the manifest shortcomings in rail performance have affected me as one of the many thousands of commuters who rely on trains to get to work each day.

Rail privatization in the United Kingdom (U.K.) was a complex affair that involved taking a single industry and breaking it up into distinct parts. It also required separate regimes of statutory regulation to oversee the general operation of the railways, the bidding process for franchised routes, and safety. The entire enterprise lacked a clear rationale. Not only did the proposals appear flawed from the outset, but the policy was pursued by an unpopular government in the face of strong opposition from the rail industry and trade unions, opposition parties in Parliament, and the public at large. After a relatively short time it became obvious that standards of service were declining alarmingly on the entire rail network, and later, the cause of serious rail accidents indicated that passenger safety was being compromised through neglect of the system.

The difficulties encountered by government in responding to what had rapidly turned into a crisis raise important legal and constitutional questions. This article begins by explaining the constitutional relationship of Parliament and the executive by mentioning the important convention of individual ministerial responsibility. Secondly, it provides a narrative of the British Rail episode that dis-

* Professor of Public Law, London Metropolitan University. This article originated from a contribution to the round table at the end of the symposium Back to Government? The Pluralistic Deficit in the Decisionmaking Processes and Before the Courts, June 2004. Papers from this symposium are published in 12 Ind. J. Global Legal Stud. 409, 409-716 (2005). I would like to thank Colin Scott and Professor Cosmo Graham for their help with the preparation of this article. This article was researched and written in the Autumn of 2004 before the Railways Acr 2005 was approved by Parliament. In consequence, it has not been possible to take full account of changes made during the later parliamentary stages of the legislation which coincided with when the article went to press. 
cusses the main features of nationalization, privatization, and statutory regulation. However, this narrative is narrowly focused in order to concentrate attention on the main institutional failings and successive attempts to repair the damage. It will be suggested that the deep-rooted problems encountered in regulating a fragmented, loss-making railway expose the limits of regulation, and perhaps the limits of the privatization project in the United Kingdom. The Labour government continues to declare its commitment to public/private partnerships and free market principles, but we will see here that in a number of key respects, the levers of control are reverting back to government.

\section{Political Accountability and Ministerial Responsibility}

When considering regulation and accountability in this context, it is important to remember that the fundamental underlying issue is the protection of an important public interest which can be identified in distinct ways. This interest can be defined in terms of the preservation of a railway that serves the public and forms an important part of the nation's transport infrastructure. And obviously, the public interest requires the efficient and safe operation of the rail network. In addition, large sums in public subsidy have been and continue to be spent on the railways. Finally, there is a public interest in the control of a monopoly power. In an important sense we are concerned with the capacity of government and of Parliament to safeguard the public interest defined in all these ways.' In the United Kingdom, the convention of individual ministerial responsibility is the constitutional mechanism for establishing accountability between political decisionmakers and professional civil servants responsible for implementing policy. Further down the policy chain, accountability extends in varying degrees to "next steps" agencies as reconstituted administrative units within the civil service; nondepartmental governmental bodies, including regulators; and to certain aspects of policy to devolved government and local government.

In a nation that functions without a codified constitution, individual ministerial responsibility has developed as part of an evolutionary process into an impor-

1. See generally C.D. Foster, Privatization, Public Ownership and the Regulation of NatuRal Monopoly (1992). 
tant constitutional convention. ${ }^{2}$ A.V. Dicey, writing in the nineteenth century, noted that "the point of defining, scrutinising and controlling public power was not to further responsiveness, representativeness and participation. Rather, the aim was to establish predictability in the exercise of power and to limit the scope of political decisions." In essence, a model of the constitution was conceived that sought to accommodate the existence of discretionary public power by the device of ministerial responsibility, and this "complemented harmoniously, without altering in essence, the Dicean concept of the rule of law. While the courts policed the boundaries of ministerial powers by reference to the common law rights of individuals, Parliament scrutinized the actions of ministers within those boundaries." ${ }^{, 4}$ In a formal and procedural sense, ministers are answerable for their departments to Parliament, and we shall soon see that any modification of this concept needs to be linked to changes in the structure of the state through privatization and regulation. ${ }^{5}$

Of course, democratic constitutional theory demanded an ultimate political accountability to the people and a model was needed that could provide a "chain of accountability," by which officials answer to ministers who answer to Parliament, which, in turn, answers to the electorate. This explains how the doctrine of ministerial responsibility emerged as the convention that described constitutional accountability. ${ }^{6}$ "The logic and history of the perception was simple: Parliament was sovereign; the Commons now dominated Parliament; therefore the Commons should, through the responsibility of ministers, monopolise political control.... British government was a unity, founded on a ministerial/parliamentary monopoly of policy making."'

2. See Colin R. Munro, Studies in Constitutional Law 55-86 (2d ed. 1999). According to A. $V$. Dicey, these "conventions, understandings, habits and practices" emerged as the way of determining how the discretionary powers of the Crown ought to be exercised. Unlike laws, conventions are not enforced by the courts, but taken together these rules and practices amount to a form of "constitutional morality."

3. Alan Beattie, Ministerial Responsibility and the Theory of the British State, in Prime Minister, Cabinet and Core Executive 158, 167 (R.A.W. Rhodes \& Patrick Dunleavy eds., 1995).

4. Ian Harden \& Norman Lewis, The Noble Lie: The British Constitution and the Rule OF LAW 86 (1986).

5. The Next Steps initiative and New Public Management have also influenced the concept but are beyond the scope of this article.

6. See Diana Woodhouse, Ministerial Responsibility, in The British Constitution in the Twentieth Century (Vernon Bogdanor ed., 2003); Diana Woodhouse, Ministerial Responsibility: Something Old, Something New, Puв. L., Summer 1997, at 262.

7. See Beattie, supra note 3, at 159 (suggesting that the Haldane Report of 1918 enshrined the Westminster model) (citation omitted). 
At one level it can be seen that executive accountability ${ }^{8}$ is acted out as a crucial part of Westminster parliamentary routine procedure. What does this mean in practice? The basic requirement is that ministers are members of Parliament. This can be either the House of Commons or the House of Lords, ${ }^{9}$ but at the same time the ministers are responsible to Parliament. In terms of general principle, executive accountability recognizes that their continuation in office as ministers depends upon the confidence and support of Members of Parliament (MPs) or Peers. In practice, when a government has a substantial majority in the House of Commons, should there be an attempt to censure the minister, the governing party can usually rely upon the support of its backbench MPs to sustain its majority. It is also possible to use individual ministerial responsibility to deflect blame for political mistakes. A resignation might identify an individual minister rather than see the government as a whole held responsible for a policy oversight. ${ }^{10}$ There are a number of ways in which ministers and their departments are routinely "answerable" to Parliament."

First, with regard to the passage of government legislation through Parliament, the relevant minister in the House of Commons or House of Lords introduces a bill concerning his or her department in Parliament, and then participates in the debate that follows. The minister appears before the standing committee that has the task of scrutinizing the measure in question. Although the minister responds to debate and may accept amendments to a bill at committee, the party whips are nearly always in position to deliver a majority for the proposed measure. This capacity of the government, once elected with an overall majority in the House of Commons, to reach its legislative objectives, often in the face of considerable opposition beyond Parliament, has been termed "elective dictatorship." 12

Second, backbench MPs are able to table questions to ministers on a regular basis. This can be a method of embarrassing the government, obtaining information,

8. Executive accountability can be defined as no more than a requirement to give reasons and explanations for actions or decisions as part of the process of government. See Adam Tomkins, The Constitution After Scott: Government Unwrapped 49 (1998).

9. There is a constitutional convention that requires the Prime Minister and the Chancellor of the Exchequer to be members of the House of Commons because of the importance of accountability to the more powerful elected chamber.

10. The resignation of Leon Brittan over the Westland Affair in 1985 serves as an example.

11. A.W. Bradley \& K.D. Ewing, Constitutional and Administrative Law 206 (13th ed. 2002).

12. Lord Hailsham, The Dilemma of Democracy: Diagnosis and Prescription 125 (1978). 
or pressing for action. The weekly Prime Minister's question time has come to be regarded as a parliamentary show piece with the focus increasingly on the respective performances of the Prime Minister and leader of the opposition party before the television cameras. In contrast, departmental questions to ministers are much more important with regard to executive accountability because they provide an opportunity to expose matters of concern within departments and pursue grievances on behalf of constituents. The Scott Report ${ }^{13}$ criticized a lack of candor by ministers that amounted to a failure by government to meet the obligation of ministerial responsibility by providing information about the activities of their departments, and it was recognized that this failure tended to undermine the democratic process. ${ }^{14}$

Third, ministers are called to account for their policies and the actions of their departments before one or more of the eighteen Departmental Select Committees. These committees, which shadow the main departments of state, have ten to fifteen members and reflect party representation in the main chamber. ${ }^{15}$ Unlike standing committees, these committees have an investigative role and conduct inquiries. ${ }^{16}$ "The topics investigated by select committees vary widely, ranging from major subjects that may take a year or longer to complete, to the latest departmental estimates and issues of topical concern..." ${ }^{17}$ Crucially, the

13. A far-reaching investigation into government was conducted by Scott. Although official U.K. policy during the war between Iran and Iraq in the 1980s was not to supply arms, behind the scenes the covert supply of a "supergun" to Iraq was in fact sanctioned by the security services. This revelation was exposed by accident when parts were discovered by customs and excise officials. The firm supplying the supergun was threatened with prosecution, and the only way to prevent the directors of the company from facing long prison terms was for their defense to expose the connection between the manufacture of these parts and the British security services. In turn, as the trial of these directors collapsed, it became clear that Parliament had been seriously misled by the government about its knowledge and involvement. To deflect criticism, an inquiry under Sir Richard Scott, an Appeal Court judge, was set up by the Prime Minister. See Report of the Inquiry into the Export of Defence Equipment and Dual-Use Goods to Iraq and Related Prosecutions 115 (1996).

14. See Tomkins, supra note 8 , at 40.

15. The present system of Select Committees was introduced in 1979. For an evaluation of the system, see David Judge, The 'Effectiveness' of the Post-1979 Select Committee System: The Verdict of the 1990 Procedure Committee, 63 PoL. Q. 91 (1992).

16. It is worth noting that the Scottish Parliament and Welsh Assembly have Subject Committees that combine the role of Standing and Select Committees. The declared objective is for specialization-to achieve a degree of expertise in a particular area. This system also addresses a criticism of the departmental committees working outside the legislative process of Parliament. See Peter Leyland, L'esperimento della devolution nel Regno Unito: uno sconvolgimento dell'assetto Costituzionale, Le Regionı, Mar.-Apr. 2000, at 341, 357.

17. Bradley \& Ewing, supra note 11 , at 211. 
committees set their own agenda by choosing what to investigate, and their work provides an opportunity for ordinary rank and file MPs to be involved in the policy process. ${ }^{18}$ These committees also promote a degree of cooperation between MPs of all parties who may identify with the broader objectives of executive accountability. Opposition MPs are always represented on these committees, and this adversarial element, with its having an interest in exposing abuse, certainly contributes to the effectiveness of the process. One of the main functions of investigations conducted by select committees is to expose the work of government to public view; the committee can provide extensive critical discussion of a policy domain by taking evidence, cross-examining witnesses, and publishing detailed reports. ${ }^{19}$ The Transport Select Committee has played a significant role in reporting on the condition of the rail network and the effectiveness of the system of rail regulation. ${ }^{20}$

Fourth, the House of Commons exercises some degree of control over government finance through the Public Accounts Committee (PAC). The remit of the PAC is limited to the audited accounts of government departments, but it is the only parliamentary committee that has substantial administrative support in the form of the National Audit Office (NAO). ${ }^{21}$ The Comptroller and Auditor General can initiate investigations of matters falling within the scope of central government. Following the collapse of Railtrack, a detailed report was published on the financial circumstances surrounding the current and future role of Network Rail in relation to the company's stewardship of the rail network. ${ }^{22}$

The performance of this scrutinizing role is an area where freedom of information has an important impact in delivering adequate accountability. The con-

18. It should also be remembered that in a somewhat different context the Parliamentary Commissioner for Administration and other public sector ombudsmen have powers to investigate specific cases of maladministration. In the case of the Parliamentary Commissioner, MPs are required to refer matters for investigation by the commissioner.

19. The reports of Select Committees are not debated in Parliament as a matter of course. This is partly due to time constraints, but this lack of follow-up undermines the work the committees undertake.

20. See House of Commons, Transport Committee, 1 The Future of the Railway: Seventh Report of Session 2003-04, HC 145-1 [hereinafter The Future of the Railway].

21. The Public Accounts Committee, which is always chaired by a senior member of the opposition, works in conjunction with the National Audit Office. The PAC investigates past government expenditure and the NAO undertakes Value for Money (VFM) audits.

22. Report by the Comptroller and Auditor General, Network Rail-Making a Fresh Start, HC 532 Session 2003-04 (May 14, 2004) [hereinafter Network Rail-Making a Fresh START]. 
vention of ministerial responsibility hinges on an obligation to provide information. Indeed, the first part of the U.K.'s Freedom of Information Act of 2000 (FOI) provides a general right of access to information held by public authorities, including government departments. But under Part II of the Act, there is a provision for class-based exemptions that permit all information within a particular class to be withheld, regardless of whether the information will cause any harm. These exclusions not only include information relating to security and intelligence matters, but also any information relating to the formulation of government policy, investigations, and proceedings carried out by a public authority. This is subject only to a public interest test which is designed to deter authorities from routinely suppressing such information. Under the FOI, the Information Commissioner can rule that material should be available in the public interest, but a major weakness is that the minister retains an ultimate veto over any such decision. ${ }^{23}$

Constitutional commentators have argued that ministerial responsibility is (and has always been) an imprecise and weak convention that fails to deliver adequate accountability and at best provides only information. ${ }^{24}$ Assuming that the minister is the architect of policy, it should follow that, should the policy design prove to be fundamentally flawed, the minister should be held accountable. If this convention operated as a clear-cut rule, then personal sacrifice in the form of resignation would be the ultimate consequence of policy failure. It is relevant to point out with regard to the forthcoming discussion of the failures associated with rail privatization that there have been no ministerial resignations. ${ }^{25}$ The evidence shows that resignations are unusual, and supports the view that normal, political considerations predominate. As Richard Crossman stated:

[Since] the Government party controls Parliament, both resignations and dismissals for incompetence have become rare. Indeed

\footnotetext{
23. See, e.g., Patrick Birkinshaw, Freedom of Information: The Law, the Practice and the IDEAL 171 (2001).

24. See Colin Turpin, Ministerial Responsibility, in The Changing Constitution 144 (Jeffrey Jowell \& Dawn Oliver eds., 3d ed. 1994). But see Adam Tomkins, What is Parliament For?, in PuBlic Law in a Multi-Layered Constitution 53 (Nicholas Bamforth \& Peter Leyland eds., 2003) (suggesting that the convention is making a comeback).

25. At least during the first Blair administration (1997-2001), Labour ministers could claim with some justification that privatization was pursued by the Conservatives from 1993 to 1996, with Labour expressing strong opposition to the policy in regard to the railways.
} 
the incompetent minister with a departmental muddle to cover up may be kept in office for years ... more votes will be lost in a general election by admitting ministerial incompetence than by concealing it. ${ }^{26}$

\section{Rail Nationalization}

In order to understand the wider issues of accountability that have arisen in this domain, it is helpful to briefly set out the constitutional significance of nationalization and privatization by briefly tracing the course of events as they unfolded. The extension of public ownership was pursued by the Labour government, mainly during the postwar administration from 1945 to 1951. The nationalized industries were placed in a special position as public corporations. As K.D. Ewing noted in his assessment of the public corporation model, "although many of the instruments of production, distribution and exchange were socialised in terms of their ownership ... this did not necessarily lead to the effective accountability of these institutions to the people on behalf of whom they were owned." ${ }^{27}$ Indeed, the rationale and the form of nationalization as it was introduced had more to do with the economic failure of the industries in question ${ }^{28}$ and their strategic importance to the overall performance of the economy than to any clear commitment to radical social ownership. In particular, the industries selected were, in nearly every case, large-scale monopolies relying heavily upon state subsidy. ${ }^{29}$ During World War II, the railways were placed under state control, but many parts of the infrastructure were severely damaged by enemy action. After the war, the Transport Act of 1947 made provision for the nationalization of the network.

British Railways came into existence on January 1, 1948. Nationalization was defended on the grounds of ensuring safety and improving labor relations.

26. R.H.S. Crossman, Introduction to Walter Bagehot, The English Constitution 43, 45 (1963).

27. See K.D. Ewing, The Politics of the British Constitution, Puв. L., Autumn 2000, at 405, 418-19.

28. See A.J.P. Taylor, ENGLish History 1914-1945, at 616 (1970) (noting that "British industrialists had got into the habit during the inter-war years of turning to the state when they ran into difficulties").

29. It should be noted that in the transport sector the four oligopolistic and loss-making U.K. rail companies (London, Midland and Scottish Railway, London and North Eastern Railway, and Great Western and Southern Railway) were nationalized in 1948 to form British Railways, later renamed British Rail. 
Also, the postwar Labour government and the Labour governments of the 1960s were committed to economic planning. "In all of these examples, a strong pragmatic case existed, in line with classical principles of free competition, for eliminating private monopoly by taking essential utilities into public ownership." ${ }^{30}$ It is interesting to note that the Conservative governments that were in power from 1951 to 1964 and 1970 to 1974 supported a "mixed" economy and denationalized only the steel industry.

The formula attributed to Herbert Morrison and applied to London Transport in the 1930s became the model for nationalization. ${ }^{31}$ This approach typically involved Parliament's passing an enabling statute that established a separate corporate identity for the industry that was exclusively owned by the state. The statute might provide for this corporation to independently raise capital by issuing bonds. Nationalized industries were exempted from direct parliamentary financial control and often received substantial government subsidies. The internal conditions of operation varied by industry, but they were not staffed by civil servants. Personnel were recruited and paid under standard contracts of employment with the corporation. While these corporations were publicly owned, they operated under a statutory framework that allowed them to function at arm's length from governmental control, while enjoying state-regulated funding or subsidies. Each year, the government laid out broad financial guidelines, leaving the board and chairman of the particular nationalized industry responsible for the day-to-day management of the organization.

I turn next to the question of constitutional accountability for the operation of these corporations. In virtually every case under the enabling statute, the relevant minister appointed a chairman who, together with a board, was given responsibility for the day-to-day operation of the corporation/nationalized industry. The minister gave final approval for strategic issues involving capital investment. ${ }^{32}$ However, government involvement did not end here because the minister could not only insist on being supplied with information, but in some cases, could give "directions of a general nature as to the exercise or performance

30. Peter Clarke, Hope and Glory: Britain 1900-1990, at 225 (1996).

31. See, e.g., TAYLOR, supra note 28 , at 352.

32. The British Rail Board was established by the Transport Act 1962, as a successor to the British Transport Commission. It consisted of a Chairman and between 9 and 15 other members with experience in transport, industrial, commercial, or financial matters. The Chairman of the Board was appointed by the Secretary of State, and the other members were appointed by the Secretary of State after consultation with the Chairman. 
by the board of their functions in relation to matters appearing to the minister to affect the public interest." ${ }^{33}$ In practice, these powers were hardly ever used, but it is widely recognized that, over time, ministers increasingly intervened in operational matters such as price setting, employment, and wages. ${ }^{34} \mathrm{With}$ regard to ministerial accountability to Parliament and select committees, it was a problem, in practice, to distinguish between day-to-day operations, which were deemed to be the responsibility of the Board, and general policy, which was the responsibility of the minister.

\section{Privatization and Regulation}

The Thatcher and Major governments' commitment to privatization during the 1980s and 1990s was ideologically motivated. It was a deliberate reversal of nationalization policy. In general, it was not difficult to find reasons for privatization. ${ }^{35}$ The structure created for nationalized industries lacked economic efficiency, and the industries themselves often failed to achieve social goals by serving consumers adequately. ${ }^{36}$ Moreover, it was argued that state-owned industries were usually monopolies that lacked any real competition. According to advocates of the privatization initiative, exposure to market conditions would impose the discipline of private business. Privatization promised to introduce a revised management structure with strong incentives to reduce overheads. In particular, savings were achieved by slimming down workforces. Further, proponents of privatization touted the prospect of weakening the powers of public sector trade unions. From the government's standpoint, privatization offered the prospect of raising revenue with an initial floating of shares and then of establishing a structure that allowed a progressive reduction of government subsidies. It was argued that market-driven economies would force down prices, which would, in the case of the railways, lead to lower fares.

33. A.H. Hanson \& Malcolm Walles, Governing Britain 208 (5th ed. 1990).

34. See Mark Thatcher, Institutions, Regulation and Change: New Regulatory Agencies in the British Privatised Utilities, 21 W. Eur. Pol. 120, 122-23(1998).

35. Political scientists have discussed the demise of classic left leaning social democracy faced with the challenge of neoliberalism. See, e.g., Anthony Giddens, The Third Way: The Renewal of Social Democracy 1-26 (1998).

36. See Cosmo Graham, Regulating Public Utilities: A Constitutional Approach 15 (2000). 
To engineer the change, shares in many of the utilities were offered to the public at favorable prices. ${ }^{37}$ For several years, privatization was a substantial source of additional public revenue, with highly publicized "sell offs" regarded as an important step in the quest for a shareholding democracy. Conservative governments aimed to achieve more efficient performance from these industries by introducing them to market pressures. However, many nationalized industries, such as the public utilities and rail, were of great importance to the economy, and privatization had far-reaching implications for consumers. In order to protect vulnerable interests and set limits on the activities of these industries, a regime of statutory regulation was established to oversee the transition to private ownership. ${ }^{38}$ These regulators were oversight agencies that were accountable to ministers. They were responsible for promoting competition, fixing prices, safeguarding the quality of service delivery, and protecting the interests of consumers and shareholders. ${ }^{39}$ A central objective of regulation involved controlling the level of profit and seeing that the pricing of goods and services takes account of the wider public interest. ${ }^{40}$

In managing the process of regulation, regulators are called on to make difficult and, at times, controversial judgments, always working within the parameters of the relevant act. The enabling legislation seeks to limit the discretion of these regulators, usually by giving the Secretary of State powers to issue directions. Following privatization, the regulators were "distanced" from the ambit of ministerial responsibility. They currently have the status of "non-ministerial government departments." The accountability problem results from the fact that the rules under which regulators operate are not subject to parliamentary

37. The list of state-owned industries that have been privatized includes: British Telecom, British Airways, British Aerospace, British Airports Authority, British Steel, British Rail, the water industry, the electricity industry, the power generation industry, and the gas industry.

38. See Tony Prosser, Regulation, Markets, and Legitimacy, in The Changing Constitution, supra note 24, at 229; Peter Leyland, UK Utility Regulation in an Age of Governance, in Public LAW in a Multi-Layered Constitution, supra note 24, at 194-202.

39. See Brian W. Hogwood, Regulatory Institutions in the United Kingdom: Increasing Regulation in the "Shrinking State," in Changing Regulatory Institutions in Britain and North America 80 (G. Bruce Doern \& Stephen Wilks eds., 1998).

40. The Littlechild Report commissioned by the Conservative government to look into this issue was strongly in favor of promoting competition. The report envisaged regulation as merely a holding operation until competition, with its supposed benefits, could be more generally achieved. See Stephen Littlechild, Regulation of British Telecommunications ProfitabilITy: Report to the Secretary of State (1983). 
approval. Moreover, there is no direct democratic accountability. In theory, the doctrine of ministerial responsibility does not extend to the privatized industry, but to the regulator. Nevertheless, ministers retain powers to appoint the regulators and to determine the extent of competition by being able to, at least partly, determine licenses that are essential to permit each industry to do business. ${ }^{4 !}$

A common criticism of the form of statutory regulation favored by government has been that too much discretion is left in the hands of regulators who can adopt an individual and highly personalized approach to conducting their task. ${ }^{42}$ The statutory framework, which mainly lays out primary and secondary duties, fails to include more detailed guidelines that set limits on discretion. "The job for the regulator, unaided by any open guidance from the government, is to decide on priorities and how to balance competing interests." ${ }^{43}$ Tom Winsor, until recently the Rail Regulator, has argued:

$[P]$ ublic interest regulation of private sector interests - of all kinds-is absolutely necessary to deal with abuses of powermarket power and other kinds of power, especially monopoly power. It is necessary to ensure the efficient and proper operation of competitive markets. And it is there to ensure that dependent users of essential facilities can get access to them on fair and affordable terms, and that these facilities are maintained and operated to the correct efficient standards at all times.

But in explaining his own view of regulation, Winsor goes on to stress that "intrusive regulation of commercial companies-whether by licence or by contract-turns them into nothing more than the unthinking managers of public or quasi-public assets." ${ }^{44}$ As we shall see later, the Transport Select Committee has been highly critical of Winsor's own style of regulation. ${ }^{45}$ In some cases, there has been undignified haggling between the industry and the regulator over impor-

41. See Peter Vass, Regulatory Reform and the Relations among Multiple Authorities in the United Kingdom, in Changing Regulatory Institutions in Britain and North America, supra note 39, at 236.

42. See Prosser, supra note 38, at 249.

43. Graham, supra note 36 , at 32.

44. Tom Winsor, The Future of the Railway, Sir Robert Reid Memorial Lecture (Feb. 10, 2004).

45. See The Future of the Railway, supra note 20, at 14-20. 
tant matters, which include competition policy, subsidies, and pricing. ${ }^{46}$ Some commentators have advocated the adoption of a "coherent regulatory philosophy," based on developing sound criteria for regulation. Such substantive principles are regarded as essential because the idea of an open market emerging by itself has proved illusory. At the same time, registration and licensing systems are costly to administer and tend to interfere with competition. ${ }^{47}$ Our discussion concerns the refinement of the regulatory environment and the powers of particular regulators in response to sustained criticism over the performance of the rail industry.

Looking at this issue from the standpoint of constitutional and administrative law, the task is to assess how effectively the systems of statutory regulation provide an adequate framework to establish constitutional accountability. Rail privatization has been the subject of considerable political and economic controversy. There were a number of aspects of the railway industry that made the above objectives much more difficult to achieve. For example, railways are a natural monopoly and require state subsidies. Notwithstanding changes in ownership, the service provider continues to dominate the market. The privatization of the rail system does not alter the fact that there is a single set of railway lines connecting rail destinations in the United Kingdom. Moreover, the rail industry continued to require substantial state subsidies after privatization. Promoting competition and consumer choice in such circumstances looked to be problematic, and was not self-evidently in the public interest. ${ }^{48}$ In another sense, the slimming down of the work force in areas such as maintenance might save costs, but at the same time, the reduction in staff could have far-reaching safety implications. Although advocates of rail privatization maintained that freeing up markets would deliver long-term benefits of efficiency, economy, and consumer choice, in reality, this has had a detrimental impact on rail services and has offered the public few, if any, advantages. It will be apparent from the analysis that follows that certain inadequacies in the regimes of regulation have contributed to the crisis on the railways.

46. Another danger is regulatory capture, where the regulator is considered to work too closely with the regulated industry.

47. See Prosser, supra note 38, at 255.

48. See Will Hutton, The State to Come 19-24 (1997) (discussing the implications of the privatization of U.K. bus services). 


\section{The Original Model of Rail Privatization and Regulation}

Rail privatization ${ }^{49}$ was achieved by separating the management of the track and infrastructure from the operation of train services and the ownership of the rolling stock. A separate company called Railtrack was formed, which inherited all the track, signaling, stations, and other property assets that were formerly in the hands of British Rail. Railtrack was made responsible for running and maintaining the infrastructure. Shares in Railtrack were floated on the stock exchange and private investors were encouraged to make investments in the newly formed company. Railtrack was responsible for leasing the track to a series of twenty-five separate regional train operating companies (TOCs). In turn, these companies took over from British Rail franchises for operating specific routes. The activities of Railtrack were overseen by the Rail Regulator (ORR) ${ }^{50}$ Initially, the ORR had responsibility for a range of consumer benefit functions, including some aspects of fares, the quality of passenger services, complaints handling and passenger complaint statistics, facilities for the disabled, and the National Rail Enquiry Service. ${ }^{51}$

It was up to the ORR to undertake periodic reviews in order to set a cap on what Railtrack was permitted to charge its customers in the form of TOCs.

49. For an overview, see Ian Bartle, Britain's Railway Crisis: A Review of the Arcuments in Comparative Perspective (2004).

50. Under section 4(1) of the Railways Act, 1993 the Secretary of State and the Regulator are placed under a duty:

to protect the interests of users of railway services; (b) to promote the use of the railway network in Great Britain for the carriage of passengers and goods, and the development of that railway network, to the greatest extent that he considers economically practicable; (c) to promote efficiency and economy on the part of persons providing railway services; (d) to promote competition in the provision of railway services; (e) to promote measures designed to facilitate the making by passengers of journeys which involve use of the services of more than one passenger service operator; $(f)$ to impose on the operators of railway services the minimum restrictions which are consistent with the performance of his functions under this Part; (g) to enable persons providing railway services to plan the future of their businesses with a reasonable degree of assurance.

Railways Act, 1993, c. 43, § 4(1) (U.K.).

51. The ORR was also responsible for the sponsorship of the Central Rail Users Consultative Committee and the regional Rail Users Consultative Committees, which came into existence on April 1, 1994. In June 2000, these organizations were renamed the Rail Passengers Council and Rail Passengers Committees. 
"The level of the TACs [track access charges] was not only crucial for Railtrack, but also for the TOCs. Many of the TOCs would be unprofitable if they were required to pay the full level of the TACs (to Railtrack)." ${ }^{52}$ A judgment was reached on the basis of a detailed assessment of business plans, asset knowledge, asset management, and procurement policies and practices. Full account was to be taken of the opportunities for higher levels of efficiency. The regulator was required to apply appropriate comparators, both within the company in question and with other enterprises doing the same or similar jobs. Prices had to be set which were fair both to the provider and to the consumer of the services in question. The TOCs received substantial subsidies from the government on the basis of the regulator's assessment, which meant that Railtrack was an indirect recipient of government subsidies. ${ }^{53}$

After privatization, train services were provided by private companies operating routes that were allocated following a bidding process. An additional regulator, the Franchising Director (Director of Passenger Rail Franchising), was given a regulatory responsibility under the Railways Act for overseeing the bidding process. ${ }^{54}$ The Franchising Director was meant to ensure that TOCs continued to provide comparable service on routes for which they had bid..$^{55}$ To this end, targets were set and the regulator was empowered to impose fines on companies that failed to meet these targets. A successful bidder was placed under a private contractual obligation with respect to the service provision. Some problems with standards of service originated at the initial franchising stage. The

52. John Stittle, Regulatory Contral of the Track Access Charges of Railtrack plc, Pub. Money \& Mgmt., Jan. 2002, at 49, 50.

53. The subsidy paid by the government in the financial year 2000-2001 was $£ 913,028,000$.

54. Under section 1(1) of the Railways Act, 1993:

The Secretary of State shall appoint-

(a) an officer to be known as "the Rail Regulator" (in this Act referred to as "the Regulator"), and

(b) an officer to be known as "the Director of Passenger Rail Franchising" (in this Act referred to as "the Franchising Director"), for the purpose of carrying out the functions assigned or transferred to the Regulator, or (as the case may be) the Franchising Director, by or under this Act.

Railways Act, 1993 c. 43, § 1(1) (U.K.).

55. Under section 23(1) of the Railways Act, 1993: "It shall be the duty of the Franchising Director from time to time to designate as eligible for provision under franchise agreements such services for the carriage of passengers by railway as he may determine ...." Railways Act, 1993, c. 43, $\S 23(1)$ (U.K.). 
package offered for several routes resulted in a lack of bidders, which led the Franchising Director to use discretionary powers to weaken the contractual terms and conditions for bidders. ${ }^{56}$ These concessions allowed the franchisees to provide services that fell below statutory requirements. At the same time, as mentioned above, the contracts negotiated with the government allowed the TOCs to receive substantial subsidies to pay for TACs. For TOCs with shortterm franchises, there was no incentive to improve services over a longer period. The final participants in the new enterprise were the rolling stock leasing companies (ROSCOs) which were formed to control the rolling stock originating from British Rail. In order for there to be a fully operational railway, the ROSCOs leased their assets (the rolling stock) to the TOCs.

\section{Industry in Crisis: Regulatory Failure?}

It is worth repeating that rail privatization in particular was controversial from the outset. ${ }^{57}$ The reliability of service delivery on most routes declined soon after the breakup of the industry. ${ }^{58}$ Later, a number of fatal accidents directly attributable to poor maintenance was a serious development, ${ }^{59}$ which drew the attention of the public and the media to the deteriorating condition of the railways. It was obvious that such a division of functions between Railtrack, TOCs, and ROSCOs created a complex interaction of "players." The actions of each of the participants needed to be fully coordinated to provide efficiency, reliability, and safety. Despite the fact that contracts set the ground rules and targets, the practical task of operating the railway was now extremely complicated.

56. There was an unsuccessful attempt to challenge by way of judicial review the decision to weaken contractual terms imposed on train operating companies. See Reduced Privatised Passenger Rail Service Lawful, Times, Dec. 12, 1995, at 40.

57. A comparison can be drawn with the privatization of the state airline, British Airways. As a single private company, British Airways was floated on the stock exchange. It retained certain advantages over rivals (e.g., take off and landing slots at Heathrow and Gatwick on many key routes), but at the same time it was exposed to wider competitive pressures on these routes and had to respond by efficiency saving (e.g., shedding staff and reducing fares to compete with rivals).

58. For graphs and supporting statistical data on reliability, efficiency, investment, and safety, see BartLe, supra note 49 , at 15.

59. There were accidents at Southall, Ladbroke Grove, and Hatfield. At Hatfield, a GNER express was derailed on the East Coast Main Line on October 17, 2000, killing 4 passengers. The cause was quickly identified as a broken rail which should have been replaced as part of routine maintenance. 
The fragmentation of roles made it particularly difficult to establish responsibility for any shortcomings. In relation to routine matters, such as a lack of punctuality and frequent cancellation of trains, train operators blamed the state of track and signaling, while Railtrack claimed that breakdowns of trains and shortages of drivers were a more frequent cause of what had become chronic un reliability.

Fundamentally, the reliance on Railtrack to maintain the infrastructure of the railways proved a central problem for the network, and also demonstrated the inadequacy of statutory regulation. ${ }^{60}$ Under the privatization provisions, Railtrack was required to lease the track to the TOCs. It followed that in order to maintain a safe and efficient service, it was crucial that Railtrack undertake an extensive investment program for track and signaling. It has been revealed subsequently that the company was failing to spend enough of its revenue on maintenance and upgrading. This shortfall in investment occurred despite increases in passenger numbers and usage of the system, which placed the infrastructure under greater strain. More usage also provided Railtrack with increased revenue in receipts from access charges, but Railtrack was only required under the Railways Act 1993 to maintain a "steady state" railway.

It was reported in the autumn of 1999 by Booz Allen Hamilton that Railtrack's infrastructure was in a worse state than it had been before privatization, despite the fact that rail investment had been doubled to $£ 2$ billion by the Conservative government in advance of the sell off. ${ }^{61}$ Moreover, the report was extremely critical of Railtrack's stewardship of the rail network, and any such problems were compounded by Railtrack's continuing lack of knowledge about the condition of its assets. Real concern was expressed because it appeared that maintenance and renewal was being driven by insufficient awareness of what was going on with regard to the day-to-day operation of the system. The report further states that there appeared to have been a decline in the underlying quality of the network's assets as a whole. While serious doubts were already being raised about the long-term

60. Martin Lodge has provided a conceptual analysis of U.K. rail regulation from a comparative perspective: "The application of an institutional approach highlights institutional linkages between policy domains and diverse policy environments and allows comparative exploration of which factors facilitate the selection of particular policy templates." Martin Lodge, Explaining Institutional Choice and Policy Transfer: The Case of British and German Railway Reform, Governance: An Int'l J. of Pol'y, Admin. \& Inst., Apr. 2003, at 159, 174. See generally Martin Lodge, On Different Tracks: Designing Railway Regulation in Britain and Germany (2002) (for a more detailed comparative discussion).

61. See Keith Harper, Pressure Mounts on Prescott, The Guardian (Manchester, Eng.), Oct. 6, 1999, at 2. 
condition and performance of the network if current rates of renewal continued, Railtrack's management focused mainly on the short-term performance of the company, while at the same time, the company was becoming increasingly remote from other bodies operating and regulating the industry.

The failure to invest was a structural problem. Under the privatization and regulation arrangements there was no financial incentive to channel revenue into upgrading the system. "The performance regimes [had been] structured to encourage focus on short run benefits rather than on longer term considerations of asset condition and network capability." 62 The company was indirectly receiving a substantial government subsidy, but for a number of years, it decided to continue paying generous dividends to shareholders, rather than divert profits from the access charges to upgrade the system. ${ }^{63}$

At this point it is also worth noting that the Rail Regulator did not adequately respond to the criticism that Railtrack had not invested enough money to enhance the network. The company's profits in the autumn of 1999 were still soaring above $\mathfrak{£} 400$ million and profits were promising to rise further. Not only were there insufficient financial incentives for Railtrack to channel more of its profits into upgrading the system, but the regulator and the government lacked any clear powers to oblige it to act in this way. No enforcement orders were ever issued against Railtrack. ${ }^{64}$ The situation was compounded because the Rail Regulator and the government took several years to recognize the extent of the neglect to the system-an oversight that, at least in part, resulted from a lack of detailed, current technical information about the condition of the railway. Moreover, the regulatory process relied on data on the state of the rail infrastructure supplied by Railtrack rather than from independent sources. ${ }^{65}$

The statutory regime provided the Rail Regulator with few options to address the issues that arose. In response to a rising tide of public complaints, the Rail Regu-

62. Booz Allen Hamilton, Report for the Rail Regulator: Railtrack's Performance in the Control Period 1995-2001 (1999), available at hrtp://www.rail-reg.gov.uk/upload/pdf/ bah-95_01.pdf (last visited Feb. 6, 2005).

63. Shareholders were given some financial recompense following the collapse of Railtrack in 2001.

64. In August 1999, the regulator announced that fines of up to $£ 40$ million would be paid out of Railtrack's profits if the company failed to meet its targets for improvements of the infrastructure.

65. Tony Bolden \& Reg Harman, Realizing the New Opportunity for Railways, Puв. Money \& Mgmт., Apr.-June 2002, at 61, 63. 
lator adopted a policy of naming and shaming companies with exceptionally poor standards of service. This approach concentrated adverse media publicity on the worst culprits, but the policy of shaming companies that were performing badly was not very effective. Companies with short-term franchises, such as Connex, the company responsible for running trains in the South East, were only interested in shortterm profitability. ${ }^{66}$ In some cases the regulator fined companies for repeated failures to meet punctuality targets and for the unreliability of the national telephone inquiry service. ${ }^{67}$ Only relatively modest fines were imposed because punitive sums would be counter-productive. This option is a blunt weapon which could have the effect of crippling the companies and causing services to deteriorate further.

The sustained level of complaints and public concern had an impact at the political level. It contributed to the replacement of the ORR on two occasions by the Secretary of State. The change in personnel resulted in a revised approach to the application of existing powers. ${ }^{68}$ It also resulted in the Secretary of State's bringing all participants together in a Spring Rail Summit in 2000 to discuss the problems confronting the industry in order to harmonize the approach to tackling them. ${ }^{69}$ These measures were too little, too late. Indeed, the seriousness of the situation was brought to the attention of the nation very dramatically by a series of fatal accidents. ${ }^{70}$ Even before Lord Cullen's report condemned Railtrack's “incompetent”

66. The treatment of Connex was strongly criticized by the Transport Select Committee:

In our view, the essence of private sector involvement is that the private sector pays if it gets its sums wrong. It is outrageous that such astonishingly large sums of taxpayers' money have been used to prop up palpably failing businesses such as $\mathfrak{f 5 8}$ million in the case of Connex. While we accept that failures in the initial franchise process may have been to blame originally, we cannot understand why action was not taken earlier by the SRA. As a result of this failure to monitor Connex properly the SRA bailed out a company using taxpayers' money only to strip it of its franchise a short time later. The SRA's management of this franchise has been woefully poor.

The Future of the Railway, supra note 20, para. 122.

67. Legal action was threatened against Railtrack by Rail Regulator Chris Bolt for failing to get halfway to its target of a $7.5 \%$ improvement in punctuality. Either a fine of up to $10 \%$ of turnover could be imposed or the shortfall could be made up by making the next year's targets even tougher. Keith Harper, Unpunctual Railtrack Faces Crackdown, The Guardian (Manchester, Eng.), Mar. 19, 1999, at 22.

68. The regulators since privatization were John Swift (1993-1998), Chris Bolt (1998-1999), and Tom Winsor (1999-2004).

69. This summit was held on June 14, 2000.

70. The accident at Ladbroke Grove, Paddington, in 1999, prompted the government to set up a public inquiry under the chairmanship of Lord Cullen. 
management, the neglect of the rail infrastructure had been exposed, particularly by the accident at Hatfield. This accident was caused by a broken piece of track. Defects in this particular section of track had been reported by an inspection some months prior to the crash, and the faulty section would have been replaced if appropriate management procedures had been in place. This revelation of inadequate maintenance led to serious safety concerns over the state of the entire rail network. Railtrack was forced to introduce a "National Recovery Plan" to rectify the neglect. The imposition of temporary speed restrictions caused delays for passengers on numerous lines and massive disruption to the traveling public over a period of many months. The emergency maintenance program cost an additional $£ 733$ million. By the time the work had been completed, Railtrack was insolvent. ${ }^{71}$ Given the managerial record of Railtrack, the then-Secretary of State, Stephen Byers, did not consider it in the public interest to pour any more resources into the company and petitioned the High Court for administration on October 7,2001. In the meantime, rail administrators were placed under a legal duty to keep the network operational. After announcing Railtrack shareholders would lose everything, the government was put under pressure to recognize the losses of shareholders and put together a compensation package providing a payout of between 250 and 260 pence per share. ${ }^{72}$ It was decided that a not-for-profit company should take over the responsibilities of Railtrack.

The failure of Railtrack, so soon after its privatization, only serves to emphasise the problems of private ownership and finance in a

71. The company had to carry the burden of cost overruns on the upgrading of the West Coast Mainline, which had risen from $£ 2.3$ billion to $£ 7$ billion.

72. See Andrew Clark, Railtrack Shareholders Will See Byers in High Court, The Guardian (Manchester, Eng.), June 30, 2004, at 14. Deloitte \& Touche, the company liquidators, reported in August 2003:

that the voluntary liquidation is proceeding in line with expectations. Subject to the Company's remaining assets being realised as expected, no further liabilities a rising, existing liabilities remaining within expectation and the Company not becoming involved in extensive litigation, we continue to expect an aggregate return to shareholders of between 252 and 260 pence per share in total.

Press Release, Deloitte \& Touche, LLP (U.K.), "Railtrack" Shareholders to Receive Second Cash Payment (Aug. 1, 2003). Railtrack investors have contributed to a $\$ 2.5$ million fighting fund to secure damages from the government for misfeasance in public office, claiming that the former transport secretary, Stephen Byers, acted unlawfully by putting the rail company into administration in 2001. Clark, supra. 
capital-intensive industry.... While the Government's case rested upon competition, efficiency and benefits to passengers, the real effect of privatization was the redistribution of wealth to the new owners and providers of finance. ${ }^{73}$

\section{Network Rail: Between Public and Private}

In reconfiguring the system, the Labour government has consistently refused to adopt the language of "renationalization," but ministers were faced with having to find an efficient method of managing the rail infrastructure that served the public interest without appearing to return the industry directly to public ownership. Network Rail is Railtrack's successor; it took over the running of the railway from the administrators in March 2002. It was formed as a not for dividend company limited by guarantee. This form of business does not have shareholders, but rather is made accountable to its members. ${ }^{74}$ It is run along commercial lines, and any operating surplus is reinvested in the rail network. This innovative structure ${ }^{75}$ ensures that investment is funded at low cost. Furthermore, the profit motive has been nullified, so that any previous suggestion of putting profit before safety is removed. Network Rail maintains, improves, and upgrades every aspect of the railway infrastructure. According to the company's mission statement, it is primarily committed to providing a consistently reliable train service. ${ }^{76}$ The fact that Network Rail was made accountable to the Strategic Rail Authority (SRA) ${ }^{77}$ has been a concern given the government's keenness for the new company to be classified as a private-sector

73. Jean Shaoul, Railpolitik: The Financial Realities of Operating Britain's National Railways, PuB. Money \& MGmt., Jan. 2004, at 27, 35. Matters of particular controversy were the pay and conditions of Railtrack's senior executives. Despite the disastrous performance of the company, senior managers increased their own salaries in line with those of private sector companies. A number of Railtrack executives received generous payoffs from 2000 to 2001.

74. The company has 114 members representing different rail interest groups.

75. Welsh Water/Glas Cymru served as a model for Network Rail. It "has a unique commercial structure within the utility sector [as] a company limited by guarantee and owned and controlled by members instead of by ordinary shareholders." Leyland, supra note 38, at 209.

76. See Network Rail, Network Rail 2004 Business Plan: A Clear Plan for a Better Railway (Mar. 31, 2004), available at http://www.networkrail.co.uk/companyinformation/businesspublications/ (last visited Feb. 25, 2005).

77. The Strategic Rail Authority is the body that was introduced to provide a new level of strategic regulation. For a fuller discussion, see infra Section VII. 
business. Network Rail requires the support of the SRA for its funding program. The equity risk is assumed by the SRA, which means that board members of Network Rail do not act as shareholders. Network Rail is not permitted to borrow money on its own account. Its short- and medium-term funding has to be supported by the SRA. A financial settlement provided revenue certainty for the 2004 to 2009 period. The capacity of the SRA and the Regulator to manage this risk effectively has been a problem, because the SRA has few direct levers on performance. $^{78}$

Network Rail shares certain characteristics with nationalized industries, such as its predecessor British Rail. Although not actually publicly owned, the infrastructure of the railways has been, in effect, placed under public control. Network Rail was established by the Department of Transport. The Secretary of State was responsible for nominating the original management and for setting the company's broad objectives. The company is entirely dependent on public funding that it receives through the SRA, and its creditworthiness is guaranteed by the government through the SRA as intermediary. ${ }^{79}$ Day-to-day management of the rail network is the responsibility of the board of directors, as was the case with British Rail. What makes it different from a nationalized industry is that the board exerts control over the general corporate policy, including the appointment of directors. At the same time, the company was made accountable to many parties, including customers, members, and, of course, the ORR.$^{80} \mathrm{Net}$ work Rail was made accountable to the public interest through the Rail Regulator using his powers under the Railways Act of 1993. It should also be noted that the company's license to run the network is established by virtue of the $1993 \mathrm{Act}$. In fact, it has been argued in assessing the crisis of 2001 that:

The collapse [of Railtrack] brought about not only a transformation of the system of rail regulation itself, but also exposed some of the central problems of the whole system of regulation-in the process challenging, and then transforming, the constitutional settlement surrounding privatization regulation far more effec-

78. See Network Rail-Making a Fresh Start, supra note 22, at 25.

79. All of Network Rail's equity risk falls ultimately on the SRA.

80. The Office of National Statistics, in a statement released on June 27, 2002, formally classified Network Rail as a private sector company. See Office of National Statistics, ONS Announces Decision on Network Rail, 1 (June 27, 2002), available at http://www.statistics.gov.uk/about/ Methodology_by_theme/rail_network/default.asp (last visited Feb. 25, 2005). 
tively and comprehensively than any of the considered reviews over the last few years. ${ }^{81}$

Moreover, the replacement of Railtrack with Network Rail through the intervention of the Secretary of State, without even consulting the regulators, amounted to a conspicuous "politicization" demonstrating that the style of technical regulation insulated from political debate had been superseded. ${ }^{82}$ The government's role in running the rail industry under the 2004 framework confirms the acceptance of a new regulatory agenda which allows ministers much greater latitude to intervene at many different levels.

\section{Reregulation Mark I: The Strategic Rail Authority}

Before the collapse of Railtrack, the government, prompted by criticisms from the House of Commons Select Committee on Environment, Transport and Regional Affairs, ${ }^{83}$ recognized the need to reform the system of regulation. ${ }^{84}$ The Parliamentary Select Committee performed an important role in crossexamining all the players in the ongoing saga of the railways and making useful recommendations. Despite manifest indications to the contrary, ${ }^{85}$ the government, as we have already observed, was not prepared to seriously consider renationalization as an option. The Labour government's first legislative response to some of these shortcomings in the regulatory framework was to form a Strategic Rail Authority (SRA). It was established under the Transport Act of 2000, but existed in shadow beginning in 1999, before commencing operation in February $2001{ }^{86}$ This body was given power, subject to the direction and guidance of the

81. Michael Moran, The British Regulatory State: High Modernism and Hyper-InnovaTION 116 (2003).

82. Id. at 118 .

83. See generally House of Commons, Environment, Transport and Regional Affairs Committee, Third Report: The Proposed Strategic Rail Authority and Railway Regulation, 19971998, HC 286-I (for recommendations on proposed regulation of the Strategic Rail Authority).

84. In the field of utilities there have been a number of attempts at modifying the schemes of regulation. See, e.g., Water Industry Act, 1999, c. 9 (Scot.).

85. See Labour Party, The Labour Party's Manifesto 1997, New Labour Because Britain Deserves Better, available at http://www.labour-party.org.uk/manifestos/1997/1997-labourmanifesto.shtml (written for the 1997 general election) (last accessed Mar. 27, 2005).

86. Transport Act, 2000, c. 38, \$§ 201-222 (Eng.). 
Secretary of State, ${ }^{87}$ to impose conditions on TOCs, and was designed to work alongside the ORR with a distinct, more strategic remit, related to overall transport policy. The SRA was placed under a statutory duty to promote and develop the rail network, and it was required to exercise its functions in a way best calculated to contribute to the achievement of sustainable development by meeting objectives set out in a ten-year plan. In exercising its functions, the SRA was required to: protect the interests of rail consumers; contribute to the achievement of sustainable development; promote efficiency and economy on the part of persons providing railway services; and promote measures designed to facilitate passengers' journeys which involve the use of the services of more than one passenger service operator (including, in particular, arrangements for the issue and use of through tickets).$^{88}$ It was anticipated that these enhanced powers would allow the SRA to play an active role in regulating fares in the interests of consumers as part of the renegotiation of the next round of rail franchises. In addition, the Transport Act of 2000 transferred consumer benefit functions and sponsorship of the Rail Passengers Council and Committees from the ORR to the SRA, as part of the Government's policy of making the SRA the one-stopshop for all customer-facing functions.

The directions and guidance from the Secretary of State have required the ORR to publish an overall strategy in January of each year, which must address the objectives relating to the operation of the railway that have been set for the SRA. This approach was designed to promote coordination of objectives and ensure that the targets set out in the SRA's ten-year plan were achieved. The SRA was also able to publish separate strategies that related to individual issues and contributed to the overall strategy. The Rail Regulator is required to ensure that, in exercising his functions, he does not prejudice the achievement of these strategies, and particularly the overall strategy, published by the SRA. The Secretary

\section{Under the Transport Act:}

[T] The Secretary of State may give the Authority-(a) directions and guidance as to the manner in which it is to exercise any of its functions in order to comply with subsections (1) to (3), and (b) directions not to exercise any of its functions in a particular manner (or not to do so without consulting, or obtaining the consent of, the Secretary of State).

Transport Act $\S 207(5)$. In Scotland, it is also subject to D\&G from the Scottish Minister for Transport, and is subject to $D \& G$ from the Mayor of London with respect to services operating within the city.

88. See Transport Act $\$ 207$. 
of State's Directions and Guidance required the SRA to summarize, as part of its overall strategy, the resources that are available to it and the basis on which priorities for the use of these resources are determined. In addition, they suggest that the SRA should describe in the overall strategy how it intends to maximize net benefits from the funds available to it. ${ }^{89}$

It is important to recognize that the SRA took over the role of the Office of Passenger Rail Franchising (the regulator responsible for overseeing the franchising process). The terms of the passenger franchises (again using a contract model) are the main mechanisms that allow the SRA to manage and direct the industry. Thus, the SRA was charged with performing the task of determining the standard of service and allocating subsidies to the individual rail companies. Many of the passenger rail franchises were set to expire by 2004. In November 2002, the SRA issued a Franchising Policy Statement that defined a new form of partnership, with the franchisees focused on delivering reliable performance, meeting passenger needs, and containing short- and long-term costs. This approach was designed to provide certainty for both existing and potential investors in the railway. Generally, the SRA envisaged franchise lengths of between five and eight years, although their duration would be dependent on the characteristics of, and risks associated with, the individual franchises. If franchisees meet key performance indicators and deliver on their plans, there is a provision for franchise extension.

Manifest limitations in the SRA's position were identified. It has been pointed out that the SRA was required to produce a strategic plan that focused on short-term priorities and failed to look at the overall future role of the railways while " $[t]$ he main questions facing the railway industry - and the country-concern the ability of the industry to contribute towards implementation of transport policy.... The rail strategy should focus on the future role, scale and funding of the railway system in this context" and future progress should depend on formulating a strategic plan based on "SWOT" (strengths, weaknesses, opportunities, threats) analysis. ${ }^{90}$ Others have commented on SR A's limited capacity to act: "It cannot direct resources to problem areas, cannot coordinate emergency responses, nor effectively shape future investment. Its role is

89. See Department for Transport, Directions and Guidance to the Strategic Rail AuTHORITY (2004) (issued on Apr. 11, 2002 \& updated on Sept. 26, 2002).

90. See Bolden \& Harman, supra note 65, at 63-64. 
hopelessly confused with the Office of the Rail Regulator." 911 The Transport Select Committee in a recent report found that: "The Strategic Rail Authority (SRA) is expected to set targets, determine outputs, grow and lead the industry as a whole, yet it has no control over the infrastructure which largely determines overall rail performance. There is therefore a serious mismatch between the SRA's objectives, powers and responsibilities. " 2 Given this catalog of shortcomings, it is not altogether surprising that as part of the proposed restructuring of the industry, on July 15, 2004, the Secretary of State set out plans to abolish the SRA through legislation and to split its responsibilities between Network Rail and the Department of Transport.

\section{Debate over Reform}

The underlying problems of the railway were not solved by the introduction of the SRA or by Network Rail's rising from the ashes of Railtrack. The combination of spiraling costs, chronic unreliability, and continuing fragmentation meant that more radical remedial action by government to attempt to rectify the situation was inevitable. In January 2004, the government announced its intention to consult regulators, private sector railway companies, and rail users prior to the publication of firm proposals to modify the instirutional framework. It is instructive to examine aspects of the conflicting viewpoints of two of the main actors.

On the one hand, as the voice of Parliament exercising its constitutional watchdog function, the Transport Select Committee has been highly critical of Railtrack, Network Rail, the Rail Regulators, ${ }^{93}$ and the government. ${ }^{94}$ In its report to Parliament, the Committee provided evidence that fragmentation in the industry, recognized as the cause of so much chaos and delay, all of which had

91. Francis Terry, The Nemesis of Privatization: Railway Policy in Retrospect, Pub. Money \& Mgmt., Jan.-Mar. 2001, at 5.

92. The Future of THE Railway, supra note 20 , at 7.

93. For the committee's criticism of the SRA, see Harper, supra note 61.

94. The Select Committee reported as part of a remit to monitor the performance of the Department for Transport and its associated public bodies. It took evidence from leading figures in the industry including the Rail Regulator and the Chairman and Chief Executive of the SRA. The Future of the Railway, supra note 20, para. 22. 
been highlighted in a previous report, was getting worse..$^{5}$ The problem was not being adequately addressed. For example, the report cited the way the Rail Regulator's Interim Review of track access charges was conducted and suggested that the Regulator and the SRA were not cooperating well. ${ }^{96}$

The committee was equally clear about other regulatory failings:

It is utterly astonishing to learn that Network Rail's Asset Register, a fundamental management tool, will now be available only in 2005, four years after a Select Committee of this House drew attention to its absence. The Regulator has clearly failed to ensure that first Railtrack and now Network Rail, have produced information needed to assess performance of the system. This is not an academic exercise. If the state of the infrastructure is not thoroughly known then reliable decisions about the levels of maintenance and renewals are simply not possible and the basis of the Regulator's Interim Review is placed in doubt. This episode demonstrates graphically how the Regulator has failed in his core function of effectively regulating the "stewardship of the national rail network." 97

95. The evidence of Dr Dieter Helm, Fellow in Economics, New College, Oxford, [to the Transport Select Committee] illustrates the appalling extent of the present confusion of responsibilities in the railway: "the Department for Transport's role is subsidiary to that of the Treasury and spending review, leaving the status of the 10 Year Plan ambiguous; the SRA's role depends on the Department for Transport's priorities, and the guidance provided to it; the SRA's budget is notionally outside the main government borrowing calculations, but in reality is determined by the Treasury; the Rail Regulator decides the track access charges which, in practice, are paid by the SRA at the margin; thus, the Rail Regulator determined how much money the SRA pays Network Rail and the TOCs [train operating companies], and therefore how much money the Treasury pays the SRA via the Department for Transport; the outputs are, however, determined by the SRA, which effectively carries out the capital planning function (which Railtrack previously did); Network Rail therefore is largely responsible for the operations of the railways, and the SRA for its capital development, confusing the roles of management and responsibility; the Rail Regulator and the SRA have a concordat which cements this confusion of roles between them."

Id. para. 7.

96. Id.

97. Id. para. 31. 
The Regulator was strongly criticized for writing off debts and overspends. This action by the Regulator demonstrated the extent of the power that the present structure had allowed the ORR to accumulate at the expense of all the other parts of the railway and the government. The committee believed the Regulator should be restraining costs and seeking value for money. Instead, the present structure permitted him to write off astonishingly large sums of public money, apparently on his own authority. ${ }^{98}$ The SRA is also targeted for criticism for failing to manage significant improvements in the face of increasing industry pressure and persistently poor performance. The Transport Select Committee concluded that since "railway is not fit for purpose," the justification for privatization had been called into question in circumstances where the government continued to bail out a failing system without taking back direct control, and the committee recommended radical reorganization. ${ }^{99}$

The former Rail Regulator, Tom Winsor, has not admitted to any failings in the way he performed his statutory duties. ${ }^{100} \mathrm{In}$ fact, he has responded robustly to the above criticisms over the determination of funding by claiming that the report from the Transport Select Committee contains many elementary factual errors which undermine its conclusions. The essence of his argument is that changing the regulatory structure after the contracts have been negotiated by a process of independent arbitration is unfair since such a change undermines a contractual framework that has already been agreed to with the private sector. The Rail Regulator, in deciding increases in expenditure which are allowed to the infrastructure provider, is required to take into account Network Rail's existing contractual commitments and also to assess and then price the reasonable requirements of the company's customers and funders. It is asserted that the state should not be in a position to change these arrangements retrospectively and thereby act as a judge in its own cause. ${ }^{101}$ This case was presented without any response to the alleged failure by the Regulator to carry out an efficient review of the asset base (a review which is meant to form the basis for any assessment). In addition, there was no recognition of the wider question of constitutional ac-

98. Id. para. 79.

99. Id.

100. In their representations prior to the 2004 White Paper, both regulators have suggested that although performance was improving, the system needed more time to bed down.

101. See Tom Winsor, 2004 Incorporated Council of Law Reporting for England \& Wales Annual Lecture, The Relationship Between the Government and the Private Sector: Winsor v. Bloom in Context, para. 31. 
countability for decisionmaking with regard to funding allocations with respect to billions of pounds worth of public money. The justification provided merely demonstrates an ideological view that accepts a restrictive, rather than interventionist, role for the state. The Regulator has interpreted his remit as accommodating public and private interests rather than prioritizing one over the other:

It is axiomatic that regulators are there to protect users of networks from abuse of monopoly power by the owners and operators of those networks, whether in excessive or unduly discriminatory pricing, the unreasonable denial of access to the network or a failure properly to operate, maintain and renew the network to appropriate standards or in a timely way. It is not always fully appreciated that the independence and jurisdiction of the regulator is also there to protect private sector investors from unjustified political interference. ${ }^{102}$

\section{Reregulation Mark II: Back to Government?}

In July 2004, the government set out plans for reorganizing the railway and overhauling the regime of regulation. ${ }^{103}$ The implications of these proposals will be considered in light of the foregoing discussion. First, the Department of Transport has assumed direct responsibility for establishing the overall strategy for the railways. ${ }^{104}$ In the words of Alistair Darling, the Secretary of State: "It must be for Ministers, accountable to Parliament and the electorate, to set the national strategy for the railways." This change of emphasis acknowledges that the government will, in the future, decide on the levels of performance and how much money to spend on the rail industry. ${ }^{105}$ Alistair Darling also stressed that it is the government that will be held accountable for these decisions in the future. This change addresses a central criticism identified by the Transport Select Committee concerning the enormous discretion previously given to the Regulator in allocating

102. Id. para. 12.

103. The main proposals contained in the White Paper were introduced in Parliament in November 2004 as the Railways Bill 2004 and were given the Royal Assent on April 4, 2005 as the Railways Act 2005 (U.K.).

104. See Railways Act 2005 s. 1.

105. Viewed in a wider political context, it will of course be the Treasury as the paymaster of the department that will ultimately determine the scale of funding available for the railways. 
funds without any direct accountability to Parliament for the consequences. Under the revised relationship between government and the Regulator, the government, which is directly accountable to Parliament, fixes the level of public funding for the railways ${ }^{106}$ by considering, in consultation with the ORR, the levels of capacity and reliability that it wants the railway to provide from that budget. $^{107}$ The ORR will then determine the precise amount of income which Network Rail needs in order to deliver these objectives. If this level of income proves inadequate, the government will be able to reconsider the levels of performance and capacity that it has set out, or to provide more funding. Despite returning many powers over rail policy to the Department of Transport, the changes also devolve authority by handing more power over local rail services to the Scottish and Welsh assemblies and to the Mayor of London. For example, it is proposed that the Mayor's Transport for London authority will dictate fares, service levels, and timetables on routes in and around the capital. ${ }^{108}$

Second, under the White Paper proposals, the reconstituted office of the Rail Regulator becomes the sole industry regulator. ${ }^{109}$ The Railways and Transport Safety Act of 2003 brought the railways into line with other regulated industries by replacing the individual regulator with a regulatory board. ${ }^{110}$ In this capacity, the ORR will be given responsibility for protecting the legitimate interest of investors and customers. The ORR will continue to exercise a mediating role by arbitrating between conflicting interests of government, Network Rail, the TOCs, and other rail stakeholders. As we have just mentioned, one of the Regulator's main tasks will be to determine Network Rail's income, which will

106. See Railways Act 2005 at pt. 2. For example, clause 6 provides a power for the Secretary of State to give financial assistance to the railways under $6(1)$ "(a) for the purpose of securing the provision, improvement or development of railway services or railway assets; or (b) for any other purpose relating to a railway or to railway services." Railways Act 2005 s. 6(1).

107. See Alistair Darling, White Paper, The Future of Rail 46 (2004) (for suggestions on "controlling the budget").

108. See id. at 52; see also Railways Act 2005 ss.15-17.

109. See Darling, supra note 107, at 61-63; Railways Act 2005.

110. In effect since July 5, 2004, the Office of Rail Regulation consists of a board of six members, headed by a chairman and chief executive. The chairman and up to four members of the board are appointed by the Secretary of State for Transport, and the majority of the board will be nonexecutive. 
involve assessing its requirements with regard to the maintenance of the rail infrastructure. ${ }^{\prime \prime \prime}$

Third, the ORR will take over responsibility for overseeing rail safety from the Health and Safety Executive. ${ }^{112}$ This modification of the regulatory framework simplifies the structure by removing the safety remit of the SRA and the Health and Safety Executive. Overseeing railway safety has been a very important regulatory issue. Although at the time of privatization responsibility for safety had been placed under the overall supervision of the Health and Safety Executive, in the initial years of privatization, Railtrack had a major role to play. ${ }^{113}$ The conflicts of interest that can arise between concerns for safety and a desire to maximize profit have already been mentioned. The alarm bells sounded loudly when a failure to place sufficient emphasis on safety contributed to a succession of fatal accidents. The Cullen Inquiry, which was set up to investigate the widely publicized fatal crash at Ladbroke Grove, found that Railtrack had not been responding to legitimate safety concerns reported by Railtrack staff. Lord Cullen accepted that the Health and Safety Executive should remain the industry regulator, but he recommended that a safety regulator, and not Railtrack, should be entirely in charge of the assessment of safety issues. It was proposed in the report that the Rail Industry Safety Board should be created as a new body, "concerned not only with standards, but also with the function of accrediting and licensing." 114 In April 2003, the Rail Safety and Standards Board (RSSB) was established. The RSSB is the rail in-

111. The specific responsibilities of the ORR will be to assess the cost of the outputs specified by the Secretary of State and to determine the size of Network Rail's income. Its role will be to regulate access contracts and arbitrate between conflicting industry interests; to help ensure that the railway provides value-for-money for both the fare-payer and the taxpayer, taking into account safety, performance, and cost; to enforce health and safety legislation with respect to the operational railway; to investigate and make recommendations on performance problems and cost overruns; to license railway operators; to exercise competition law functions concurrently with the Office of Fair Trading, where these relate to the railways; and to act as a single repository for rail industry data.

112. See Railways Act 2005 s.2.

113. See generally Stanley Hall, Hidden Dangers: Railway Safety in the Era of PrivatisaTION (1999).

114. Lord Cullen, Health and Safety Commission, The Ladbroke Grove Rail Inquiry, Part 2 Report: Progress Report to March 2002, $\S 1.39$, at http://www.hse.gov.uk/railways/paddrail/ lgri2.pdf (last visited Mar. 27, 2005). Other functions are the promotion of safety within the industry, establishing and managing system authorities, funding and sponsoring research and development, monitoring and reporting on the industry's safety performance, developing the annual Railway Group Safety Plan, disseminating good practice, and providing safety leadership. 
dustry's lead body on safety and standards matters, and it monitors safety and reports on safety performance at regular intervals. ${ }^{115}$ As part of this most recent upheaval, the Government has decided to simplify the safety regulatory structure for the railways by transferring responsibility for railway safety from the Health and Safety Executive to the Office of Rail Regulation. ${ }^{116}$ Alistair Darling stated in Parliament, "[Safety regulation] should be in with the bricks. And it needs a clear industry focus to make sure that safety is an integral part of operations." 117 This change is justified on the grounds that the ORR will be independent of the Government and the industry.

The fourth feature of the revised structure is confirmation that the not-forprofit company Network Rail will be directly responsible for ensuring that the network delivers a reliable service. This objective will be achieved by means of an agreement with the Department of Transport. The company will be primarily responsible for the day-to-day running of the railway system; this will include timetables, punctuality, and passenger services. Network Rail "will be accountable to passengers and freight users for performance of the network." 18 As we have seen in the past, Railtrack, private maintenance companies, and TOCs have been able "to pass the buck for poor performance." The Government has responded to the previous degree of fragmentation and, in particular, the criticism that there was no single player with operational responsibility. ${ }^{119}$ In

115. Railway Group Standards Code, Jan. 19, 2004, § 1.2.2, confirms that "[ $t$ the RSSB's primary objective shall be to lead and facilitate the Railway Industry's work to achieve continuous improvement in the health and safety performance of the railways in Great Britain and thus to facilitate the reduction of Risk to passengers, employees and the affected public so far as is reasonably practicable, so aiding compliance by providers of railway services with their obligations under health and safery law."

116. An expert working for the HSE expressed strong opposition to the proposal of combining safety regulation: "Capturing the safety regulator ... would, at a stroke, reverse the modernisation [of the regulatory structure], increase the complexity of interfaces and destroy public assurance that there is an independent safety regulator." Allan Sefton, Director of Rail Safety, Health and Safety Executive, Effective Cost Control and Risk Management, Rail Review Seminar (York, Apr. 23, 2004).

117. Alistair Darling, Statement to the House of Commons (July 15, 2004). This process is likely to be completed some time in 2005.

118. See id.

119. To address the problem caused by the fragmentation of the network it was stressed by the Secretary of State that "Network Rail would coordinate restoring services following disruptionsending a sometimes chaotic situation where different train companies and the infrastructure operators were hobbled and leaderless." Back on Track, The Guardian (Manchester, Eng.), July 16, 2004. 
the future, "[t]he Government will set out what services Network Rail is to deliver, and Network Rail will take on new responsibilities, including leading industry planning, setting timetables and directing service recovery." 120

Moreover, although not directly part of the latest white paper, the decision by Network Rail to return to in-house maintenance has further simplified the management of the network. At the time of its collapse, Railtrack had been committed to a three-year contract with a private company (Jarvis) to undertake maintenance of the rail infrastructure. The spiraling costs of this commitment was one of the factors that led to Railtrack's financial difficulties (another factor was the failure of the private sector to adequately perform its duty). The October 2003 announcement by Network Rail that maintenance was to be returned to inhouse was a further significant change in the approach to running the railway. Over the last fifteen years, private sector companies have increasingly assumed responsibility for public service provision, with their role set out under contract. The decision to restore the upkeep of the railway to Network Rail bucks this trend; reverting to in-house maintenance puts Network Rail in a position to not only make cost savings, ${ }^{121}$ but to directly control its own maintenance program. It also means that, despite its designation as a private sector company, Network Rail, at least with respect to the operation of the infrastructure, has assumed the guise of British Rail prior to privatization. ${ }^{122}$

The issue of constitutional accountability arises not only in relation to the regulators, but in relation to the policy that applies to the industry and how that policy is implemented. The task becomes a matter of delineating accountability by establishing clarity over the division of responsibility between ministers, operators, and regulators. ${ }^{123}$ It is worth remembering that, under nationalization, an attempt was made to distinguish the functions of the minister from that of the industry board, with the minister assuming responsibility for "general policy" and the board being responsible for day-to-day operations. Under the revised structure the government is assuming direct responsibility for policy issues. Net-

120. Darling, supra note 117.

121. It is estimated the change to in-house maintenance will bring immediate annual savings from anything ranging from $£ 170$ to $£ 300$ million per year. The figure could increase to $£ 900$ million by 2008-09 which would represent a 31.8\% reduction in costs. See Richard Hope, UK Brings Infrastructure Maintenance Back In-House, Railway Gazette Int'L, June 2004, at 345.

122. For the time being, renewals work and major projects such as the upgrading of the West Coast Mainline will remain with the private sector.

123. See Graham, supra note 36, at 196. 
work Rail is clearly responsible for operations and will be performing its own maintenance, while the Regulator oversees the process. In other words, a key objective has been to establish much greater clarity over the division of responsibility between minister, operator of infrastructure, and regulator.

Finally, one of the most obvious results of this change has been the abolition of the SRA. The Government's decision to follow this path implicitly recognizes the failure of its own previous attempt to improve the regulatory framework. The majority of the functions of the SRA, including all its financial obligations (e.g., in regard to funding allocation), are transferred to the Secretary of State. The Department for Transport takes on the responsibility of awarding train operating company franchises.

\section{Conclusion}

The near collapse of the U.K. railway network in recent years has been discussed as a way of looking at the effectiveness of constitutional accountability mechanisms designed to oversee and regulate the privatization of a state monopoly transport provider. In an industry where a strong public interest remained after privatization, the nature of the problem, namely the fragmentation of the railway system and increasing unreliability of the railways post-privatization, was already apparent when Labour was returned to office in 1997. Parliament has served as a focus for public discontent and a forum for discussion and debate. In accordance with the convention of ministerial responsibility, government ministers answered parliamentary questions. The Select Committee on Transport conducted a number of in-depth investigations and, in doing so, cross-examined the main players. The committee reported and made critical observations and positive recommendations. Ministers were perhaps guilty of prevarication and delay, but the government responded not merely by giving assurances that corrective measures would be introduced but by acting. The regulators were replaced. The regulatory structure was modified with the introduction of the Strategic Rail Authority. Network Rail was formed to take over Railtrack's mantle. Likewise, within the bounds of their statutory remit, the regulators sought to secure improvements in industry performance. However, the analysis provided here has revealed that the degree of fragmentation and confusion was so pronounced that none of the existing agencies, including government and regulators, appeared to have the capacity to manage such a complex mix of players with overlapping, and often conflicting, interests and responsibilities. 
The transport secretary, when announcing the latest proposals, including the dissolution of the independent SRA, rejected the idea that they amounted to a form of "quasi-renationalization." ${ }^{24}$ In an era of governance, it is doubtful whether the previous brand of nationalization would be seen as viable anyway, but I would argue that the latest package in many respects represents a return to government. The restoration of powers to the minister, coupled with the modification in regulatory structure, means that apart from setting the cash limits available to the industry for maintaining and developing the infrastructure, the Department of Transport has assumed the overall role of the SRA. From now on, ministers will be directly responsible for awarding rail franchises and establishing fare policies. Furthermore, the chairman and up to four members of the board of the ORR are appointed by the Secretary of State for Transport. The role of the ORR is closely tied to that of the government. The infrastructure is run by a not-for-profit company formed by the government dedicated to providing a reliable service. Network Rail has taken the maintenance of the infrastructure back in-house. Although not directly resembling the position previously in place under nationalization, the government has assumed an even more prominent role in running the rail industry. ${ }^{125}$ Indeed, the proposals have been welcomed because "this white paper puts the onus for the overall operation of the railways where it belongs: back with the government," 126 and because the rail industry paymaster is directly accountable to Parliament. An obvious disadvantage of reverting to this position is that an industry financially dependent on government is highly susceptible to short-term changes in policy unless there is an unexpected turnaround in the profitability of the industry that makes it an attractive proposition for private investors.

The latest proposals establish clearer channels of accountability and remove some of the overlapping layers of regulation simplifying the chain of command. However, the government decided against accepting the proposal of Richard

124. See Darling, supra note 117; Darling, supra note 107. The Government has stated repeatedly that it believes that the best way to secure the objectives is through maintaining the principle of public and private partnership, but without the poorly structured relationships and incentives that have hampered the industry in its current form.

125. Under the nationalization model it was "the Minister whose approval is required for the corporation's capital investment programmes [and it] is he, together with the Chancellor of the Exchequer, who has to sanction the raising of capital finance from external sources." Hanson \& WALLES, supra note 33, at 208.

126. Back on Track, supra note 119. 
Bowker (former chairman of the SRA) for a single public sector National Rail body to act as a "client" for private train operators and, as a result, the government has not eliminated a divided national railway system. "Train operators, rolling-stock leasing companies, Network Rail, the ORR, and the department of transport-along with a regional government in places-will make up the various layers involved in getting a train from A to B."127

The setting of regulatory priorities to control monopolies of such national importance as the railways should be the task of government overseen by Parliament. Regulators can be required to follow guidelines of good procedure and practice, ${ }^{128}$ but the search will prove elusive for what Professor Prosser has termed a "coherent regulatory philosophy" in the form of a set of general principles, ${ }^{129}$ which, for example, might allow regulators to navigate between the complex considerations confronting them to achieve a balance between consumer interests and private interests. The open-ended brief conferred upon a previous generation of regulators has been largely replaced by establishing a new set of priorities. For example, a social obligation has to be fulfilled by ensuring reasonable pricing levels, and thus a fair deal for consumers. Equally, new economic imperatives have to be achieved at a macro level by ensuring that the railways contribute to an integrated transport policy and at a micro level by ensuring that taxpayers underwriting the system derive value for money. In addition, the public must be protected by guarantees that the railways are safe to use. Of course, drawing up the route map to achieving such goals by promoting the coordination of players remains a formidable challenge. Now, I am leaving for work, hoping to catch the Silverlink 8:21 running on the North London Line from Hampstead Heath to Highbury and Islington. Am I any more likely to arrive on time? The saga of our British Railways continues. ${ }^{130}$

127. Id.

128. Examples of obvious requirements would be establishing consultation procedures, general transparency, and the giving of reasons for decisions.

129. Prosser, supra note 38 , at 255.

130. See, e.g., Andrew Clark, Railways On the 'Way to Recovery': First Profit and Fewer Delays, ThE Guardian (Manchester, Eng.), Nov. 27, 2004, available at http://www.guardian.co.uk/ business/story/0,3604,1360891,00.html (last visited Apr. 17, 2005). This favorable assessment reported by Transport Correspondent, Andrew Clark, was based on data released by Network Rail. For example, it reported an improvement in punctuality of $1 \%$, with $82 \%$ of services running on time. However, a massive stride in efficiency is still required to reach the relatively modest punctuality target of $90 \%$ set for 2009. 